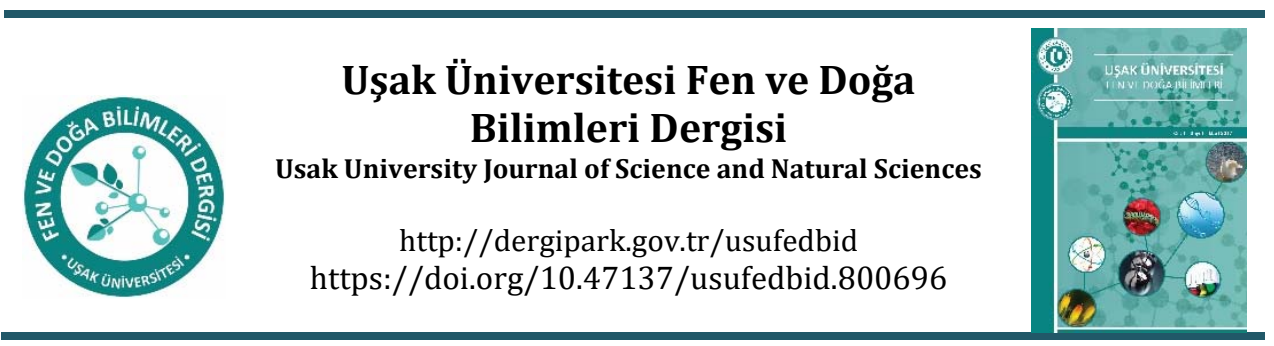

Araştırma makalesi

\title{
Uşak İli Ekolojik Koşullarında Bazı Keten Hat ve Çeşitlerinin Verim ve Tarımsal Özelliklerinin Belirlenmesi
}

\author{
Özlem Aslan1, Ercüment Osman Sarıhan ${ }^{*}$ \\ Tarla Bitkileri Bölümü, Ziraat Fakültesi, Ușak Üniversitesi, Ușak, Türkiye
}

\begin{abstract}
This study was carried out in the research and application field of Faculty of Agriculture, Uşak University in 2019. In the study, it was determined the yield and some agronomical characteristics of some linen (Linum usitatissimum L.) varieties and lines in the ecological conditions of Uşak province. The study was conducted with randomize complete block design with three replicates. Some agronomical characters were measured as yield per decare $(\mathrm{kg} / \mathrm{da})$, plant height $(\mathrm{cm})$, technical stem length $(\mathrm{cm})$, number of capsules (number/plant), number of branches (number/plant) and number of seeds in a capsule (number/capsule). Seed yield per decare 80,0-185,3 kg/da; plant height values 39,9-65.9 cm; technical stem length 28,6-46.7 cm, thousand seed weight 5,2-6.1 g, the number of capsules 6,20-41.17 per plant were obtained. According to these results; Lirkskoppe, Fibra, Ötztaler, Plenny and local varieties Sarı-85 were determined as the cultivars with the best results in terms of yield and some agricultural characteristics in Uşak province.
\end{abstract}

Keywords: Flax, linseed, agronomical characters, yield.

\section{Özet}

$\mathrm{Bu}$ çalışma 2019 yılında Uşak Üniversitesi Ziraat Fakültesi araştırma ve uygulama tarlasında yürütülmüştür. Çalışmada yurtdışı kökenli bazı keten (Linum usitatissimum L.) çeşit ve hatlarının Uşak ili ekolojik koşullarındaki verim ve bazı tarımsal özellikleri belirlenmesi amaçlanmıştır. Araştırma tesadüf blokları deneme desenine göre 3 tekrarlamalı olarak yürütülmüştür. Dekara verim (kg/da), bitki boyu $(\mathrm{cm})$, teknik sap uzunluğu $(\mathrm{cm})$, kapsül sayısı (adet/bitki), dal sayısı (adet/bitki) ve kapsüldeki tohum sayısı (adet/kapsül) özellikleri incelenmiștir. Elde edilen bulgulara göre; keten genotiplerinin dekara verimi 80,0-185,3 kg/da; bitki boyu 39,9-65,9 cm; teknik sap uzunluğu 28,6-46,7 cm, bin dane ağırlığı 5,26,1 g, kapsül sayısı 6,20-41,17 adet/bitki arasında değişmiştir. Bu sonuçlara göre Uşak ilinde1; Lırkskoppe, Fibra, Ötztaler, Plenny ve yerli çeşit Sarı-85 verim ve tarımsal özellikler bakımından en iyi sonuçların alındığı çeşitler olarak belirlenmiştir.

Anahtar Kelimeler: Keten, tarımsal karakterler, verim.

\footnotetext{
*Corresponding author:

E-mail: ercument.sarihan@usak.edu.tr ORCID ID: 0000-0002-5892-1561
} 


\section{Giriş}

Son yıllarda Türkiye'de tıbbi ve aromatik bitkilerin yetiştiriciliği üzerinde artan ilgi bir söz konusudur. Türkiye'de bir çok il bazında yapılan tarımsal desteklemelerle tıbbi ve aromatik bitkilerin yetiștiriciliği geliștirilmeye çalıșılmaktadır. Tıbbi ve aromatik bitkilerin, sahip oldukları etken maddeler nedeniyle, başta tamamlayıcı tıp uygulamalarında ve ilaç hammaddesi olarak ilaç endüstrisinde olmak üzere, baharat, bitkisel çay, gıda, kozmetik, vb. bir çok alanda değerlendirilmeleri söz konusudur. Tıbbi bitkiler içerisinde değerlendirilebilecek olan keten bitkisinin de bu kapsamda yetiştiriciliğinin geliştirilmesi gerekmektedir. Keten Dünya'da Mısırlılar döneminden günümüze tarımı yapılagelen ve değişik amaçlarla da kullanılan bir bitkidir. Keten bitkisi Amerika'da Ulusal Kanser Enstitüsünün, kanseri önleyici gıdalar arasına aldığı ve üzerinde çalışılmasını öngördügü altı bitkisel materyalden birisidir [1]. Türkiye'de de çok eskiden beri kültürü yapılan keten bitkisinin zaman içerisinde ekim alanları ne yazık ki birkaç dekar alana kadar düşmüştür. Bunun en önemli sebebi lif bitkisi olarak yetiştirilen bu bitkiden elde edilen lifin pamuk ve sentetik liflerle rekabet edememesidir. Ayrica yeterli ve verimli yerli keten çeşitlerinin geliştirilememesi, tescilli yerli çeşitlerin sayısının günümüzde oldukça az olması, fiyat istikrarsızlıkları ve kırsaldan kente göçlerin artması, hastalık ve zararlılara karşı yaşanan verim kayıpları ve teknik tarım uygulamalarının yetersizliği gibi nedenler de bunda etkili olmuştur. Keten lif bitkisi olduğu kadar aynı zamanda tohumlarındaki yağı nedeniyle de önemli bir yağ bitkisidir. Keten (Linum usitatissimum L.) tek ylllı bir kültür bitkisidir. Genellikle mavi veya beyaz çiçeklere sahip olan keten bitkisi, 30-100 cm arasında bitki boyuna sahiptir. 4-6 mm uzunlukta, esmer kahverengi, kırmızımtırak veya sarı renkte yassı, parlak, susam tohumunu andıran, kokusuz, yağlı ve lezzetli tohumları vardır. Bitkinin tohumları; yüksek miktarda lif ve protein kaynağıdır. Ayrıca düşük karbonhidrat içeriğine sahip olması nedeniyle de önemli bir gıda ve endüstri bitkisidir. Tohumlarında bulunan yağında omega 3 yağ asidi içeriği oldukça yüksektir. Keten tohumlarında magnezyum, bakır, fosfor ve B1 gibi mineral ve vitaminler de söz konusudur. Bu alanda tohum ve lif verimi yüksek, hastalık ve zararlılara dayanıklı yerli çeşitlerin geliştirmesi önemli ve zorunludur. Türkiye genelinde birçok ilde keten yetiştiriciliğini geliştirmek amacıyla yapılmış çok sayıda çalışma söz konusudur [2-8]. Ancak, Uşak ili ekolojik koşullarında keten bitkisiyle ilgili çalışmalar bulunmamaktadır. Bu nedenle, Uşak koşullarında üretim ve ıslah çalışmalarında kullanılabilecek üstün çeşit ve hatların belirlenmesi önem arz etmektedir.

Bu çalışmayla, yabancı kökenli keten hat ve çeşitlerinin, yerli Sarı 85 keten çeşidine göre sahip olabilecekleri üstün özellikleri belirlenmeye çalışılmıştır. Uşak ili ekolojik koşullarına uygun keten çeşitlerinin belirlenmesi ve yerli çeşitlerin geliştirilmesi amacıyla yapılacak ıslah çalışmalarında kullanılabilecek, tarımsal açıdan iyi özellik gösteren keten hat ve çeşitlerinin tespit edilmesi amaçlanmıştır.

\section{Materyal ve Yöntem}

Bu çalışma, 2019 yılında Uşak Üniversitesi Ziraat Fakültesi Araştırma ve Uygulama Alanında yürütülmüştür. Çalıșmada 20 adet yabancı kökenli keten (Linum usitatissimum L.) çeşit ve hattı ile yerli çeşit olan Sarı 85 (kontrol) çeşidi materyal olarak kullanılmıştır. Kullanılan hat ve çeşitlerin menşei Tablo 1'de sunulmuştur. Çalışmada kullanılan yabancı kökenli hat ve çeşitler Ankara Üniversitesi Ziraat Fakültesi Tarla Bitkileri Bölümünden temin edilmiştir.

Denemede tüm hat ve çeșitler tesadüf blokları deneme desenine göre 3 tekrarlamalı olarak ekilmişlerdir. Denemede parseller $30 \mathrm{~cm}$ sıra arası ve $3 \mathrm{~m}$ sıra uzunluğu olacak 
şekilde hazırlanmış ve nisan ayında her parselde 3'er sıra halinde ekimler gerçekleștirilmiștir. Deneme yerinden ekim öncesi alınan toprak örneği numunesiyle deneme yerinin toprak özellikleri tespit edilmiștir. Toprak analizleri Ușak İl Tarım ve Orman Müdürlügü laboratuvarında yaptırılmıștır (Tablo 2). Hasat temmuz ayında yapılmıștır. Parselden hasat edilen bitkiler üzerinde çeșitli ölçümler yapılmıștır. Çalışmada her parselden tesadüfi seçilen 10 'ar adet bitkide ölçümler yapılmıştır. Bitki boyu $(\mathrm{cm})$, teknik sap uzunluğu $(\mathrm{cm})$, kapsül sayısı (adet/bitki), dal sayısı (adet/bitki), kardeş sayısı (adet/bitki), kapsüldeki tohum sayısı (adet/kapsül), bin dane ağırlığı (gr) ve dekara tohum verimi $(\mathrm{kg} / \mathrm{da})$ gibi karakterler ölçülmüş ve ortalama değerleri tespit edilmiștir.

Tablo 1. Denemede materyal olarak kullanılan keten hat ve çeşitlerinin menşei

\begin{tabular}{|c|c|c|c|c|c|}
\hline $\begin{array}{c}\text { Sira } \\
\text { no }\end{array}$ & $\begin{array}{c}\text { Çeşit ve / veya } \\
\text { Hat Adı }\end{array}$ & Menşei & $\begin{array}{c}\text { Sira } \\
\text { no }\end{array}$ & $\begin{array}{c}\text { Çeşit ve / veya } \\
\text { Hat Adı }\end{array}$ & Menşei \\
\hline 1 & Sorauer 7 & Avusturya & 12 & Hargita 3. Sz. E. & Macaristan \\
\hline 2 & Ötztaler & “ & 13 & Linda & “ \\
\hline 3 & Ötztaler x Lussatia & “ & 14 & Emerande & “ \\
\hline 4 & Ohv Lehn & “ & 15 & Cha-419-052 & “ \\
\hline 5 & Belan & Çekoslavakya & 16 & Blenda & Almanya \\
\hline 6 & Texa & “ & 17 & Feinflax & “ \\
\hline 7 & Norman & “ & 18 & Hollandia & “ \\
\hline 8 & Flanders & “ & 19 & Liral Prince & “ \\
\hline 9 & Fibra & Macaristan & 20 & Lirkskoppe & “ \\
\hline 10 & Plenny & “ & 21 & Sarı 85 & Türkiye \\
\hline 11 & Pinacle & “ & & & \\
\hline
\end{tabular}

Deneme yerinin toprak analizi sonuçları Tablo 2'de sunulmuştur. Bu sonuçlara göre deneme yeri; hafif alkali karakterli, organik maddesi oldukça az, orta kireçli ve killi-tınlı yapılı bir toprak yapısına sahiptir. Makro bitki besin maddeleri bakımından deneme yerine ait toprağı azot içeriğinin ve fosfor içeriğinin oldukça düşük olduğu, potasyum içeriğinin ise yeterli olduğu görülmektedir.

Tablo 2. Deneme yerine ait toprak analizi sonuçları

\begin{tabular}{ccccc}
\hline $\begin{array}{c}\text { Toprak } \\
\text { orneği }\end{array}$ & pH & $\begin{array}{c}\text { Tuz } \\
\left(\mathbf{m i k r o S ~ c m} \mathbf{~}^{-1}\right)\end{array}$ & Kireç \% & $\begin{array}{c}\text { Organik madde } \\
(\mathbf{\%})\end{array}$ \\
\hline$(0-30 \mathrm{~cm})$ & $\begin{array}{c}\text { Hafif alkali } \\
(7.70)\end{array}$ & $\begin{array}{c}\text { Hafif Tuzlu }(1 \\
059)\end{array}$ & Orta kireçli $(9.1)$ & Çok az $(0.084)$ \\
\hline & & & & \\
\hline $\begin{array}{c}\text { Toprak } \\
\text { örneği }\end{array}$ & Yapı & $\begin{array}{c}\text { Toplam Azot } \\
(\%)\end{array}$ & Faydalı P (ppm) & Faydalı K (ppm) \\
\hline$(0-30 \mathrm{~cm})$ & Killi-Tinlı & Fakir $(0.042)$ & Çok fakir $(0.56)$ & Yeterli (250) \\
\hline
\end{tabular}

Denemede ölçümü yapılan karakterlere ilişkin elde edilen ortalama değerlere ait varyans analizleri Mstat-C istatistik paket programıla analiz edilmiş ve elde edilen ortalamalar arasındaki farklar ise Duncan testi ile belirlenmiștir.

\section{Bulgular ve Tartışma}

Denemede ölçümü yapılan tüm tarımsal özelliklere ait ortalama değerler arasındaki farkların istatistiki olarak 0.01 seviyesinde önemli olduğu belirlenmiştir. Buna göre bitki boyu, teknik sap uzunluğu, kapsül sayısı ve dal sayısı karakterlerine ait ortalama değerler 
ve farkları Tablo 3'de; kardeș sayısı, verim, kapsüldeki tohum sayısı, bin dane ağırlığı karakterlerine ait ortalama değerler ve farkları Tablo 4'de sunulmuștur.

Denemede keten çeşit ve hatlarına ait bitki boyu değerleri 39,9-65,9 cm arasında değișmiștir. Lırkskoppe çeșidi $(65,9 \mathrm{~cm})$ en uzun boylu çeșit olarak belirlenmiștir. $\mathrm{Bu}$ çeșidi sırasıyla Liral Prince, Hollandia, Fibra ve Ohy Lehn çeșitleri takip etmiștir. Denemede 5 adet çeșidin bitki boyunun $60 \mathrm{~cm}$ 'nin üzerinde olduğu görülmektedir. Denemede en kısa boylu çeșit Norman çeșidi $(39,9 \mathrm{~cm})$ olmuștur. Yerli çeșit olan Sarı-85 $(42,7 \mathrm{~cm})$ ise kısa boylu çeşitler arasında yer almıştır. Denemede bitki boyu bakımından değerlendirilen çeşit ve hatların istatistiki olarak 11 farklı grupta yer aldığı görülmektedir.

Tablo 3. Bitki boyu, teknik sap uzunluğu, kapsül sayısı, dal sayısı ve kardeş sayısı karakterlerine ait ortalama değerler ve farkları

\begin{tabular}{|c|c|c|c|c|c|}
\hline $\begin{array}{l}\text { Sira } \\
\text { No }\end{array}$ & Çeşit ve Hatlar & $\begin{array}{c}\text { Bitki Boyu } \\
\text { (cm) }\end{array}$ & $\begin{array}{c}\text { Teknik Sap } \\
\text { Uzunluğu } \\
\text { (cm) }\end{array}$ & $\begin{array}{c}\text { Kapsül Sayısı } \\
\text { (adet/bitki) }\end{array}$ & $\begin{array}{c}\text { Dal Sayısı } \\
\text { (adet / bitki) }\end{array}$ \\
\hline 1 & Sorauer 7 & $58,2 \mathrm{~cd}$ & $37,9 \mathrm{~g}$ & $18,03 \mathrm{fg}$ & 4,4 de \\
\hline 2 & Ötztaler & $54,7 \mathrm{e}$ & $42,1 \mathrm{de}$ & $9,43 \mathrm{k}$ & $2,9 \mathrm{fg}$ \\
\hline 3 & Ötztaler x Lussatia & 56,8 de & 44,4 bc & $13,50 \mathrm{ij}$ & $3,4 \mathrm{f}$ \\
\hline 4 & Ohy Lehn & 60,2 bc & $38,8 \mathrm{fg}$ & $16,80 \mathrm{fgh}$ & $4,8 \mathrm{~d}$ \\
\hline 5 & Belan & $47,9 \mathrm{gh}$ & $38,6 \mathrm{fg}$ & $7,87 \mathrm{kl}$ & $3,2 \mathrm{fg}$ \\
\hline 6 & Texa & $49,7 \mathrm{fg}$ & 40,9 de & $6,20 \quad 1$ & $2,7 \mathrm{~g}$ \\
\hline 7 & Norman & $39,9 \mathrm{k}$ & $28,6 \mathrm{~m}$ & $12,43 \mathrm{j}$ & $3,9 \mathrm{e}$ \\
\hline 8 & Flanders & $45,2 \mathrm{hl}$ & $34,8 \mathrm{ij}$ & $21,33 \mathrm{e}$ & 4,3 de \\
\hline 9 & Fibra & $61,2 \mathrm{~b}$ & $45,2 \mathrm{ab}$ & $18,60 \mathrm{f}$ & $4,7 \mathrm{~d}$ \\
\hline 10 & Plenny & $41,6 \mathrm{jk}$ & 33,6 ij & 41,17 a & $7,1 \mathrm{~b}$ \\
\hline 11 & Pinacle & $51,8 \mathrm{f}$ & $32,6 \mathrm{jk}$ & $36,70 \mathrm{~b}$ & $6,1 \mathrm{c}$ \\
\hline 12 & Hargita $3 \mathrm{Sz} \mathrm{E}$ & $48,2 \mathrm{~g}$ & $34,1 \mathrm{lj}$ & $18,40 \mathrm{f}$ & $4,6 \mathrm{~d}$ \\
\hline 13 & Linda & $49,5 \mathrm{fg}$ & $35,5 h_{1}$ & $24,13 \mathrm{~d}$ & $6,2 \mathrm{c}$ \\
\hline 14 & Emerande & $46,8 \mathrm{gh}$ & $31,1 \mathrm{kl}$ & $21,37 \mathrm{e}$ & $4,6 \mathrm{~d}$ \\
\hline 15 & Cha-419-052 & $47,8 \mathrm{gh}$ & $33,4 \mathrm{lj}$ & $27,23 \mathrm{c}$ & $5,7 \quad c$ \\
\hline 16 & Blenda & $58,4 \mathrm{~cd}$ & $42,9 \mathrm{~cd}$ & 22,13 de & 4,2 de \\
\hline 17 & Feinflax & $48,2 \mathrm{~g}$ & $37,4 \mathrm{gh}$ & 15,70 ghı & $2,8 \mathrm{~g}$ \\
\hline 18 & Hollandia & $62,8 \mathrm{~b}$ & 40,6 ef & 14,50 hij & $4,4 \mathrm{de}$ \\
\hline 19 & Liral Prince & $62,7 \mathrm{~b}$ & $44,5 \mathrm{bc}$ & $17,17 \mathrm{fg}$ & 4,3 de \\
\hline 20 & Lirkskoppe & 65,9 a & 46,7 a & 21,70 e & $4,6 \mathrm{~d}$ \\
\hline \multirow[t]{2}{*}{21} & Sarı 85 & $42,7 \mathrm{ij}$ & $30,2 \mathrm{~lm}$ & $38,33 \mathrm{~b}$ & 7,7 a \\
\hline & LSD & 2,571 & 2,006 & 2,294 & 0,5113 \\
\hline
\end{tabular}

Keten çeşit ve hatlarına ait teknik sap uzunluğu değerleri 28,6-46,7 cm arasında değișmiștir (Tablo 3). Bu karakterde de bitki boyu karakterinde olduğu gibi Lırkskoppe çeşidi $(46,7 \mathrm{~cm})$ en uzun teknik sapa sahip çeşit olmuştur. Bu çeşidi sırasıyla Fibra, Liral Prince, Ötztaler x Lussatia ve Blenda çeşitleri takip etmiştir. Denemede en kısa teknik sap uzunluğuna sahip çeşit Norman çeşidi $(28,6 \mathrm{~cm})$ olmuştur. Yerli çeşit olan Sarı-85 (30,2 $\mathrm{cm}$ ) ise kısa teknik sapa sahip çeşitler arasında yer almıştır. Denemede teknik sap uzunluğu bakımından değerlendirilen çeșit ve hatların istatistiki olarak 11 farklı grupta yer aldığı görülmektedir.

Kapsül sayısı değerleri 6,20-41,17 adet/bitki arasında değişmiştir. Plenny çeşidinin (41,17 adet/bitki) en fazla kapsül sayısına sahip çeşit olduğu belirlenmiștir. Denemede en az kapsül olușturan çeșit olarak Texa çeșidi (6,20 adet/bitki) tespit edilmiștir. Yerli çeșit olan Sarı-85 (38,3 adet/bitki) ise en fazla kapsül oluşturan çeşitler arasında yer almıştır. 
Denemede kapsül sayısı bakımından değerlendirilen çeşit ve hatların istatistiki olarak 12 farklı grupta yer aldığı görülmektedir (Tablo 3 ).

Dal sayısı değerleri 2,7-7,7 adet/bitki arasında değișmiștir (Tablo 3). Yerli çeșit Sarı-85 (7,7 adet/bitki) en fazla dallanma gösteren çeșit olmuștur. Bu durum bu çeșidin yağlık özelikte bir çeșit olmasından kaynaklanmaktadır. Denemede en az dallanma gösteren çeșit olarak Texa çeșidi $(2,7$ adet/bitki) tespit edilmiștir. Denemede dal sayısı bakımından değerlendirilen çeşit ve hatların istatistiki olarak 7 farklı grupta yer aldığı görülmektedir.

Denemede kardeş sayısı değerleri 1-3,17 adet/bitki arasında değişmiştir. Plenny çeşidi (3,17 adet/bitki), Pinacle (3,03 adet/bitki) ve yerli çeşit Sarı-85 (3 adet/bitki) en fazla kardeş oluşturan çeşitler olmuştur. Bu durum bu çeşidin yağllk özelikte bir çeşit olduğunu bir kez daha göstermektedir. En az kardeș oluşturan çeşit olarak Ötztaler çeşidi (1 adet/bitki) tespit edilmiştir. Bu aslında bu çeşidin tek saplı olduğunu dip kısmından kardeş sap oluşturmadığını göstermektedir. Denemede kardeş sayısı bakımından değerlendirilen çeşit ve hatların istatistiki olarak 10 farklı grupta yer aldığı görülmektedir (Tablo 4).

Tablo 4. Kardeş sayısı, Verim, Kapsüldeki tohum sayısı, Bin dane ağırlığı karakterlerine ait ortalama değerler ve farkları.

\begin{tabular}{|c|c|c|c|c|c|}
\hline $\begin{array}{l}\text { Sira } \\
\text { no }\end{array}$ & Çeşit ve Hatlar & $\begin{array}{l}\text { Kardeş sayısı } \\
\text { (adet /bitki) }\end{array}$ & $\begin{array}{l}\text { Verim } \\
\text { (kg/da) }\end{array}$ & $\begin{array}{c}\text { Kapsüldeki } \\
\text { tohum sayısı } \\
\text { (adet/kapsül) }\end{array}$ & $\begin{array}{c}\text { Bin dane } \\
\text { ağırlığı } \\
\text { (gr) }\end{array}$ \\
\hline 1 & Sorauer 7 & $2,7 \mathrm{~b}$ & $108,7 \mathrm{hl}$ & 6,1 hı & $5,2 \mathrm{~g}$ \\
\hline 2 & Ötztaler & $1,0 \mathrm{j}$ & 146,7 ef & $6,5 \mathrm{gh}$ & $5,9 \mathrm{ab}$ \\
\hline 3 & Ötztaler x Lussatia & $1,1 \mathrm{ij}$ & $102,3 \mathrm{ij}$ & 5,9 I & 5,8 bc \\
\hline 4 & Ohy Lehn & $1,8 \mathrm{de}$ & $116,7 \mathrm{~h}$ & $6,5 \mathrm{gh}$ & $5,8 \mathrm{bc}$ \\
\hline 5 & Belan & $1,1 \mathrm{ij}$ & $174,3 \mathrm{~b}$ & $6,1 \quad 1$ & 5,8 bc \\
\hline 6 & Texa & 1,3 ghı & $130 \mathrm{~g}$ & $6,1 \mathrm{hl}$ & 5,7 bcd \\
\hline 7 & Norman & 1,4 fgh & $131,7 \mathrm{~g}$ & $6,7 \mathrm{~g}$ & 5,7 bcd \\
\hline 8 & Flanders & 1,6 ef & $102,3 \mathrm{ij}$ & 7,6 bcde & 5,4 efg \\
\hline 9 & Fibra & $1,9 \mathrm{~d}$ & $156,0 \mathrm{~cd}$ & 8,1 a & $5,3 \mathrm{fg}$ \\
\hline 10 & Plenny & 3,17 a & $100,0 \quad \mathrm{lj}$ & 7,8 abc & $5,3 \mathrm{fg}$ \\
\hline 11 & Pinacle & $3,03 \mathrm{a}$ & 80,0 & $8,0 \quad a b$ & 5,4 efg \\
\hline 12 & Hargita 3 Sz E & $1,77 \mathrm{de}$ & $138,7 \mathrm{fg}$ & $6,0 \quad 1$ & 5,5 def \\
\hline 13 & Linda & $2,0 \mathrm{~d}$ & $85,3 \quad l$ & $7,1 \mathrm{f}$ & 5,7 bcd \\
\hline 14 & Emerande & $1,9 \mathrm{~d}$ & $152,3 \mathrm{de}$ & $6,7 \mathrm{~g}$ & 5,4 efg \\
\hline 15 & Cha-419-052 & $2,37 \mathrm{c}$ & $113,7 \mathrm{~h}$ & 7,4 cdef & 5,6 cde \\
\hline 16 & Blenda & 2,5 bc & $88,7 \mathrm{kl}$ & 7,3 ef & 5,7 bcd \\
\hline 17 & Feinflax & $1,27 \mathrm{gh}$ & $97,0 \mathrm{jk}$ & 7,7 abc & 5,8 bc \\
\hline 18 & Hollandia & $1,2 \mathrm{hij}$ & $157,7 \mathrm{~cd}$ & 7,3 def & $5,3 \mathrm{fg}$ \\
\hline 19 & Liral Prince & $1,5 \mathrm{fg}$ & $138,7 \mathrm{fg}$ & 7,7 bcd & $5,5 \mathrm{def}$ \\
\hline 20 & Lirkskoppe & 1,6 ef & 185,3 a & $7,1 \mathrm{f}$ & 5,4 efg \\
\hline \multirow[t]{2}{*}{21} & Sarl 85 & 3,0 a & $163,7 \mathrm{c}$ & $7,8 \mathrm{ab}$ & $6,1 \mathrm{a}$ \\
\hline & LSD & 0,2152 & 8,843 & 0,3501 & 0,2152 \\
\hline
\end{tabular}

Dekara verim değerleri 80-185 kg/da arasında değișmiştir. Lırkskoppe (185,3 kg/da) en fazla verim oluşturan çeşit olmuştur. Bu çeşidi 174,3 kg/da verimi değeri ile Belan çeşidi takip etmiştir. Yerli çeşit olan Sarı-85 çeşidi $(163,7 \mathrm{~kg} / \mathrm{da})$ de en yüksek verime sahip olan çeşitler arasında 3. sırada yer almıştır. Bu durum bu çeşitlerin yağlık özelikte bir çeşit olduğunu göstermektedir. Ayrıca Lırkskoppe çeşidi tohum verimi bakımından en iyi çeşit olurken, bitki boyu bakımından da en uzun boylu çeşit olmuştur. Bu da çeşidin hem tohum hem de lif açısından üzerinde durulması gereken bir çeşit olduğunu 
göstermektedir. En az verim oluşturan çeșit ise Pinacle çeşidi $(80 \mathrm{~kg} / \mathrm{da})$ olmuştur. Denemede verim değerleri bakımından değerlendirilen çeşit ve hatların istatistiki olarak 12 farklı grupta yer aldığı görülmektedir (Tablo 4).

Denemede kapsüldeki tohum sayısı değerleri 5,9-8,1 adet/kapsül arasında değişmiştir. Fibra çeșidi (8,1 adet/kapsül) en fazla kapsülünde tohum olușturan çeșit olmuștur. Kapsülünde en az tohum olușturan Ötztaler x Lussatia hattı (5,9 adet/kapsül) olmuștur. Denemede kapsülündeki tohum sayısı değerleri bakımından değerlendirilen çeșit ve hatların istatistiki olarak 9 farklı grupta yer aldığı görülmektedir (Tablo 4).

Bin dane ağırlığı değerleri 5,2-6,1 g arasında değişmiştir (Tablo 4). Yerli çeşit olan Sarı85 (6,1 g) en fazla bin dane ağırlığına sahip çeşit olmuştur. Bu çeşidi 5,9 g ile Ötztaler çeşidi takip etmiştir. Bin dane ağırlığı en az olan çeşit ise Sorauer 7 çeşidi $(5,2$ g) olmuştur. Denemede bin dane ağırlığı değerleri bakımından değerlendirilen çeşit ve hatların istatistiki olarak 7 farklı grupta yer aldığı görülmektedir (Tablo 4).

Dünyada çeşitli yerlerde keten çeşit ve hatlarıyla ilgili yapılan çok çeşitli çalışmalar söz konusudur. $\mathrm{Bu}$ çalışmalar ile keten bitkisinin uyum sağlayacağ çeşitli yerler belirlenmektedir. Bu amaçla Dünya'da ve Türkiye'de yapılan çalışmalarda bazı keten hat ve çeşitlerinde belirlenen bazı tarımsal özelliklere ilişkin araştırma sonuçları aşağıda sunulmuştur.

Yapılan bir çalıșmada; en yüksek bitki bașına tohum verimi (1,20 g/bitki) Flanders çeșidinden elde edilmiștir. Yağ oranı ve yaklașık enerji değeri bakımından ise Midin (\%36,8-450,5 kcal) ve Norman çeşidinden (\% 36,6-454,9 kcal), karbonhidrat $(\% 9,62)$ ve kül içeriği ise $(\% 4,23)$ bakımından ile McGregor çeșidinden elde edilmiştir [2].

Verim, sap sağlamlı̆̆ı, bitki boyu, olgunluk süre bakımından orta değerlere sahip Antares keten çeşidi ve Sarı-85 keten çeşitleriyle yapılan bir çalışmada; en yüksek bitki boyu, bitki ağırlığı ve net asimilasyon oranı; Antares keten çeşidinden, 20 oC toprak sıcaklığında yapılan ekiminden elde edilmiștir. En yüksek kök uzunluğu ve oransal kök ağırlı̆̆ ise Sarı-85 keten çeşidinin, 20 oC toprak sıcaklığında yapılan ekiminden, en yüksek oransal gövde ağırlığı ise Sarı-85 keten çeşidinin, 15 oC toprak sıcaklı̆̆ olduğunda yapılan ekiminden elde edilmiștir. Araștırma sonucunda; bitki büyümesi bakımından, Samsun ekolojik koşullarında kıșlık ekim zamanının toprak sıcaklığının 20 oC civarında olduğu ekim ayında yapılması gerektiği sonucuna varılmıștır [3].

Bazı yağ keteni (Linum usitatissimum L.) çeşitlerinin Konya sulu koşullarında verim ve verim unsurlarını belirlemek amacıyla, 2016 yılı vejetasyon döneminde (Nisan-Ağustos) yürütülmüș bir çalıșmada; materyal olarak Sarı-85 ve 12 adet yabancı kökenli (Midin, Linda, Barbara, Atalanta, Antares, Lirina, Royal, Norman, Olin, Raulin, Dakota, Mikael) olmak üzere toplam 13 adet yağlık keten çeşidi kullanılmıştır. Tohum verimi bakımından Lirina (243.8 kg/da), Sarı-85 (237.0 kg/da) ve Atalanta $(219.0 \mathrm{~kg} / \mathrm{da})$ çeşitlerinin Konya sulu koşulları için önerilebileceği kanısına varılmıştır [4].

Samsun ekolojik koşullarına uygun kışlık keten çeşitlerinin belirlenmesi amacıyla, Karadeniz Tarımsal araştırma Enstitüsünde, 2001-2003 yılları arasında yürütülen bir başka çalışmada; bitki boyu, bitkide kapsül sayısı, kapsülde tane sayısı, bitkide tane sayısı, 1000 tane ağırlı̆̆ı yağ oranı ve verim karakterleri incelenmiştir. Antares ve Bionda keten çeşitlerinin diğer çeşitlere göre Samsun ekolojik koşulları için daha uygun oldukları belirlenmiştir [5]. 
Tekirdağ koşullarında 11 faklı keten çeşidiyle (Sarı-85, Raulin, Flanders, Avangarc, Linda, Dakota, Royal, Norman, Mcbregor ve Atalanta ) üç farklı ekim zamanında (8-9 Kasım, 1819 Kasım ve 24 Kasım) ekim yapmıștır. Dekara en yüksek tohum verimi I. ekim zamanından ve Sarı-85 çeșidinden $(220.06 \mathrm{~kg} / \mathrm{da})$, en düșük tohum verimini ise III. ekim zamanından ve Mc Bregor çeșidinden $(100.51 \mathrm{~kg} / \mathrm{da})$ elde etmiștir. Elde edilen sonuçlar da göze alınarak Tekirdağ koşullarında Sarı-85 çeşidinin yetiştiriciliğinin uygun olacağı ifade edilmiştir [6].

Diyarbakır şartlarında kışlık olarak ekimi yapılan 11 ayrı keten çeşidiyle yapılan bir çalıșmada; bitki boyu 52,1-64.3 cm, dal sayısı 4,3-6,6 adet/bitki, kapsül sayısı 23,9-45,4 adet/bitki, 1000 tane ağırlığının 2,9-5,0 g, tohum veriminin 32,6-53,6 kg/da ve yağ oranının ise \%30-36 arasında değişme göstermiştir [7].

Van ekolojik koşullarında yapılan bir çalışmada 11 farklı keten çeşidinin (Atalanta, Antares, Sarı-85, Raulin, Mikael, Linda, Flanders, Norman, McGregor, Dakota ve Royal) verim ve verim unsurları değerlendirmiştir. Çalışmada; deneme yıllarına göre en yüksek tohum (141.7-149.0 kg/da) ve yağ (49.8-50.8 kg/da) veriminin Linda keten çeşidinden elde edildiğini belirtmiştir [8].

Dufferin isimli Kanada'da ıslah edilmiş keten çeşidinin ortalama veriminin $161.4 \mathrm{~kg} / \mathrm{da}$, bitki boyunun $54 \mathrm{~cm}$, yağ oranının \% 42.1 olduğu tespit edilmiştir [9].

Kanada'da yapılan bir çalışmada da yazlık keten çeşitlerinde bitki boylarının $45-90 \mathrm{~cm}$ arasında değiștiği, tohum yağ oranlarının \%37-45 arasında olduğu, tohum veriminin ise 81-109 kg/da arasında değiştiği belirtilmiştir [10]. Yapılan bir diğer çalıșmada yă keteninde verim ortalamasının $190 \mathrm{~kg} / \mathrm{da}$, bitki boyunun $60-75 \mathrm{~cm}$, bitki başına kapsül sayısının ise 10-15 adet/bitki iken kapsülde yer alan tohum sayısının 6-8 arasında değiștiği ifade edilmiștir [11]. Bitki sıklığına bağlı olarak keten bitkisinde yan dal sayısı (3,5-12,5 adet/bitki); kapsül sayısı (3,4-13,1 adet/bitki); kapsüldeki tohum sayısı (7-7,8 adet/bitki) arasında değişme gösterdiği belirlenmiştir [12].

Azotlu gübrelemenin (0, 4 ve $6 \mathrm{~kg} / \mathrm{da})$ ve sulamanın (1, 2 ve 3 defa) keten bitkisinde tohum verimlerini arttırdığı belirlenmiştir. Gübrelemeyle tohum verimleri sırasıyla 31,1 $\mathrm{kg} / \mathrm{da}, 46,7 \mathrm{~kg} / \mathrm{da}, 57,9 \mathrm{~kg} / \mathrm{da}$ olarak gerçekleşirken; sulamayla sırasıyla tohum verimleri $40,7 \mathrm{~kg} / \mathrm{da}, 45,2 \mathrm{~kg} / \mathrm{da}$ ve $49,9 \mathrm{~kg} / \mathrm{da}$ olmuştur [13]. Keten bitkisinde tohum verimine en çok bitki başına tohum ve sap verimlerinin etki ettiği bunu bitki boyu ve dal sayısı gibi karakterlerin izlediği vurgulanmıștır[14].

Ketende ekim zamanı da verim üzerine etkili olan bir diğer faktördür. Erken ilkbaharda mart ayında yapılacak ekimin nisan ayında yapılacak ekime göre daha iyi sonuç verdiği ve verimin yüksek olduğunu belirtmiştir [15].

Ankara ekolojik koşullarında yapılan diğer bir çalışmada; 215 yabancı kökenli keten çeşit ve popülasyonunun değerlendirildiği çalışmada; 41 adet keten popülasyonu ve çeşidinde bitki boyu değerlerinin yüksek olduğu; 70,68-79,67 cm arasında değiştiği, bunların ıslah materyali olarak seçim yapılabileceği belirtilmiştir. Bitki başına tohum verimlerinin ise 12 adet çeşit veya popülasyon da ortalama 1,39-2,20 gr arasında değiştiği belirtilmiștir [16].

Yukarıda belirtilen çalışmaların birçoğunda kullanılan yerli keten çeşidi olan Sarı-85 değişik yörelere uyum sağlayan en iyi çeşitler arasında yer almıştır [3-4, 6, 8]. Bu çalışmada da Sarı-85 çeşidi Uşak yöresine uyum sağlayan çeşitler arasında yer almıştır. 
Yukarıda belirtilen çeşitlerden farklı çeşitlerle yürütülen bu çalışmada, Uşak ekolojik koşullarına Lırkskoppe, Belan, Sarı-85, Hollandia, Fibra ve Emarande gibi keten çeşitlerinin en iyi uyum sağlayan çeşitler olduğu belirlenmiştir.

\section{SONUÇ ve ÖNERÍLER}

Elde edilen sonuçlara göre Uşak ekolojik koşullarında yürütülen bu çalışmada; yurt dışı kökenli bazı keten çeşit ve hatlarının verim ve bazı tarımsal özellikleri değerlendirilmiștir. Elde edilen bu sonuçlara göre Uşak ilinde tohum amaçlı yapılacak keten tarımında yüksek verim açısından kullanılabilecek çeşitler arasında Lırkskoppe, Belan, Sarı 85, Hollandia, Fibra ve Emarande, çeşitleri belirlenmiștir. Lif amaçlı yetiștiricilik de ise Liral Prince, Hollandia, Fibra ve Ohy Lehn çeşitlerinin uzun boylu çeşitler olarak ön plana çıktığı görülmüștür. Ancak tek yıllık olarak sürdürülen bu çalışmada elde edilen sonuçlara göre, belirlenen çeşitler ile Uşak ekolojik koşullarında yapılacak daha uzun süreli çalışmalara ihtiyaç vardır. Uşak ekolojik koşullarına en uygun keten hat ve çeșitlerinin belirlenmesi ile ileride yapılacak ıslah çalışmalarına da hız verilebilecektir.

\section{TEŞEKKÜR}

$\mathrm{Bu}$ çalışma, Uşak Üniversitesi Lisansüstü Eğitim Enstitüsü, Tarım Bilimleri Anabilim Dalı'nda yüksek lisans tezi olarak yürütülen bir çalışmasından hazırlanmıştır.

Denemede materyal olarak kullanılan keten hat ve çeşitlerinin teminini sağlayan; Ankara Üniversitesi, Ziraat Fakültesi Tarla Bitkileri Bölümü emekli öğretim üyesi Prof. Dr. Neşet Arslan ve Uşak Üniversitesi Ziraat Fakültesi Tarla Bitkileri Bölümü öğretim üyesi Doç. Dr. Mehmet Uğur Yıldırım'a teşekkür ederiz.

\section{Çıkar Çatışması Beyanı}

Makale yazarları aralarında herhangi bir çıkar çatışması olmadığını beyan ederler.

\section{Kaynaklar}

1. Olalı H ve Duymaz İ. Tarımın Türk ekonomisindeki yeri ve ekonomik gelişmeye katkısı. İzmir: İzmir Ticaret Borsası Yayınları; 1987.

2. İşleroğlu H, Yıldırım Z, Yıldırım M. Fonksiyonel bir gıda olarak keten tohumu. GOÜ, Ziraat Fakültesi Dergisi, 2005; 22(2):23-30.

3. Arslan O, Kahrıman, F, Topçu Bayram Ö, Turhan H. Çanakkale koşullarında yetiştirilen keten genotiplerinin tohum verimi ve bazı kalite özelliklerinin incelenmesi. Tekirdağ Ziraat Fakültesi Dergisi (Journal of Tekisdag Agricultural Faculty, 2011; 8(3):1-7.

4. Bozkurt D, Kurt O. Ekim zamanının keten (Linum usitatissimum L.)'in kantitatif büyümesine etkisi. OMÜ Zir. Fak. Dergisi (J.of. Fac. Of Agric., OMU), 2007; 22(1):34-40.

5. Örs Ö, Öztürk Ö. Konya koşullarında yağlık keten (Linum usitatissimum L.) çeşitlerinin verim ve bazı tarımsal özelliklerinin belirlenmesi. Selcuk Journal of Agriculture and Food Sciences, 2018; 32(3):305-311.

6. Kurt O, Doğan H, Demir A. Samsun ekolojik koşullarına uygun kışlık keten çeşitlerinin belirlenmesi üzerinde bir araştırma. OMÜ Zir fak. Dergisi ( J.of Fac of Agric OMU), 2006; 21(1):1-5. 
7. Tanman D. Tekirdağ koşullarında kışlık ekim zamanlarının bazı keten (Linum usitatissimum L.) çeşitlerinin verim ve verim özelliklerine etkisinin araştırılması. Namık Kemal Üniversitesi Fen Bilimleri Enstitüsü Tarla Bitkileri Anabilim Dalı Yüksek Lisans Tezi, Tekirdağ, 2009; 50s.

8. Karaaslan D ve 0 Toncer. Diyarbakır koşullarında bazı keten çeşitlerinin adaptasyonu üzerine bir araştırma. Türkiye 4. Tarla Bitkileri Kongresi, 2001; 1721, Tekirdağ.

9. Tunçtürk M. Van koşullarında bazı keten (Linum usitatissimum L. ) çeşitlerinin verim ve bazı verim öğelerinin belirlenmesi. Tarım Bilimleri dergisi, 2007; 13(4):365-371.

10. Kenaschuk EO. Dufferin Flax. Canadian Journal of Plant Science, 1977; 57: 977978.

11. Hume DJ. Oil and Protein Seed Crops. Notes on Agriculture, 1982; 18:17-18.

12. Crowley DN. Effect of Nitrogen and Phosphorus on Linseed. Field Crop Abstract, 1988; 33:334-340.

13. Diepenbrock W, İwerson D. Yield Development in Linseed. Plant Research and Development, 1989; 30:104-124.

14. Ghatak S,Sounda G, Chatterjee P. Effect of Different Levels of Nitrogen and İrrigation on Yield and Yield Attributing Characters of Linseed (L. usitatissimum L.). Environment and Ecology, 1990; 8-1B:383-386.

15. Saad AMM. A Factor Analysis of Plant Variables Related to Seed Yield in Flax. Annals of Agricultural Society University of Wales, 1995; 74:95-104.

16. Uzun Z. Ketende ekim zamanı ve ekim sıklı̆̆ının verim ve verim öğelerine etkisi. A.Ü.Z.F., Tarla Bitkileri Anabilim Dalı Yüksek Lisans Tezi, Ankara, 1992.

17. Yıldırım U. Yabancı kökenli keten (Linum usitatissimum L.) çeşit ve populasyonlarının bazı bitkisel özellikleri. Ankara Üniversitesi Fen Bilimleri Enstitüsü, Tarla Bitkileri Anabilim Dalı, Ankara, 1998; 109s. 